\title{
Optimasi Temperatur Pada Produksi Biogas dari Limbah Rumah Makan di Kota Pontianak
}

\author{
(1) *Sri Rezeki, (2) Wivina Diah Ivontianti, ${ }^{(3)}$ Aslami Khairullah \\ ${ }^{(1,2,3)}$ Jurusan Teknik Kimia, Fakultas Teknik, Universitas Tanjungpura, Jl. Prof. Dr. Hadari Nawawi, Pontianak \\ *E-mail: sri.rezeki@invent.untan.ac.id \\ Diterima: 20.05.2021 Disetujui: 29.05.2021 Diterbitkan: 30.05.2021
}

\begin{abstract}
The wastes that resulted from the restaurant activities are potentially to be used as raw materials in biogas production since it contains a lot of organic materials which consisted of carbohydrates, proteins, and fats that are able to be biodegraded. In the formation of biogas, temperature is one of the key aspects which is possible to influence the growth of microorganisms and the reaction speed. Therefore, besides to investigate the amount of biogas that could be produced from restaurant's organic wastes in Pontianak City, this research also was aimed to investigate the optimum temperature in biogas convertion from restaurant's organic waste in Pontianak City. The biogas production process was carried out using the restaurant's organic waste as the substrates and EM-4 as the starter. The anaerobic digestion process used a batch reactor with temperature variations: 35 , 40 , and $55^{\circ} \mathrm{C}$. Based on the research, it was known that restaurants in Pontianak City were able to produce 23,630 kg/day organic wastes in average which could be converted became $7,408 \mathrm{~m}^{3} \mathrm{~kg}^{-}$ ${ }^{1} V S d a y^{-1}$ biogas. At the mesophilic condition $\left(35^{\circ} \mathrm{C}\right), 4,700 \mathrm{~mL}$ of biogas was produced; meanwhile at the mesophilic temperature $(45)^{\circ} \mathrm{C}, 6,900 \mathrm{~mL}$ of biogas was resulted; and additionally at the thermophilic temperature $\left(55^{\circ} \mathrm{C}\right), 7,350 \mathrm{~mL}$ of biogas was formed. It was concluded that the optimum temperature in this study was $55^{\circ} \mathrm{C}$.
\end{abstract}

Keywords: biogas, restaurant, optimum temperature, Pontianak.

\begin{abstract}
ABSTRAK
Limbah rumah makan dapat dijadikan bahan baku pembuatan biogas karena banyak menghasilkan material organik yang mudah untuk diurai oleh mikroorganisme seperti karbohidrat, protein, dan lemak. Dalam pembentukan biogas, suhu adalah salah satu faktor yang dapat mempengaruhi perkembangbiakkan mikroorganisme dan kecepatan reaksi. Oleh karena itu, selain untuk menganalisis besaran potensi biogas yang dapat diproduksi dari sampah organik rumah makan di Kota Pontianak, penelitian ini juga bertujuan untuk menemukan temperatur optimum pada konversi biogas dari sampah organik rumah makan di Kota Pontianak. Proses produksi biogas dilakukan menggunakan substrat limbah organik rumah makan dan EM-4 sebagai starter. Proses anaerobic digestion menggunakan reaktor batch dengan variasi temperatur: 35,40 , dan $55^{\circ} \mathrm{C}$. Berdasarkan penelitian yang telah dilakukan diketahui bahwa rumah makan di Kota Pontianak dapat menghasilkan sampah organik ratarata $23,630 \mathrm{~kg} /$ hari yang berpotensi untuk dikonversi menjadi $7,408 \mathrm{~m}^{3} / \mathrm{kg}$ VS/hari biogas. Pada kondisi mesofilik $35^{\circ} \mathrm{C}$ dihasilkan $4.700 \mathrm{~mL}$ biogas, sedangkan pada suhu mesofilik $45^{\circ} \mathrm{C}$ dihasilkan sebanyak $6.900 \mathrm{~mL}$ biogas, dan pada suhu termofilik $55^{\circ} \mathrm{C}$ dihasilkan produksi biogas sebanyak 7.350 $\mathrm{mL}$. Maka temperatur optimum dalam penelitian ini adalah $55^{\circ} \mathrm{C}$.
\end{abstract}

Kata kunci: biogas, rumah makan, temperatur optimum, Pontianak

\section{Pendahuluan}

Salah satu jenis usaha yang pada saat ini tumbuh dengan pesat di Kota Pontianak adalah usaha di bidang kuliner. Semakin bertambahnya jumlah rumah makan, kafe, atau restoran yang ada di Kota Pontianak, akan berdampak pada peningkatan jumlah sampah organik yang diproduksi. Sampah organik rumah makan atau restoran merupakan limbah yang bersumber dari aktivitas dapur, seperti potongan sayuran, daging, ayam, atau ikan yang tidak termasak; minyak goreng sisa memasak; ataupun bekas makanan juga minuman yang tidak terkonsumsi oleh para pengunjung (Rezeki, dkk., 2019). 
Sebagai perbandingan, menurut Dewilda, dkk. (2019), kuantitas sampah dari rumah makan di Kota Padang pada tahun 2018 adalah sebanyak $0,105 \mathrm{~kg}$ per orang per hari atau sejumlah $0,139 \mathrm{~kg}$ per $\mathrm{m}^{2}$ per hari dimana komposisi sampah makanan yang terbanyak adalah sampah organik sebesar 70,69\% dengan komposisi terbesar berasal dari sampah sisa makanan.

Apabila limbah rumah makan ini dibuang ke lingkungan maka akan menimbulkan berbagai dampak negatif. Sampah rumah makan ini harus ditangani dengan baik, salah satunya dengan cara digunakan sebagai bahan utama dalam produksi biogas karena banyak mengandung polisakarida, asam amino, dan lipid yang dapat didegradasi secara biologi (Wahyono dkk., 2012). Telah dilaporkan bahwa sampah organik dari rumah makan terdiri atas $11,8-74 \%$ polisakarida, $13,8-18,1 \%$ komponen asam amino, dan 3,78-33,72\% lipid (Bong, et al, 2017).

Temperatur dapat mempengaruhi perkembangbiakkan bakteri dan laju reaksi dalam pembentukan biogas (Wati dan Prasetyani, 2011). Konversi biogas dapat terjadi dalam 2 kondisi temperatur optimum, yakni mesofilik $\left(35^{\circ} \mathrm{C}\right)$ dan termofilik $\left(55^{\circ} \mathrm{C}\right)$ (Kahar, dkk., 2019). Darmanto, dkk., (2012), telah mengkaji pengaruh temperatur mesofilik dan termofilik pada pembentukan biogas dari kotoran kuda, dimana hasil optimum diperoleh pada kondisi termofilik. Menurut Sari, dkk., (2018), dan Santoso (2010), meningkatnya pengkondisian temperatur akan meningkatkan hasil produksi gas. Ketika temperatur lebih tinggi aktivitas mikroorganisme akan lebih tinggi atau aktif. Salah satu karakter mikroorganisme termofilik adalah memiliki tingkat perkembangbiakkan yang lebih cepat dibandingkan dengan perkembangbiakkan mikroorganisme pada temperatur mesofilik. Pembelahan membran sel dalam proses pertumbuhan pada mikroorganisme termofilik terjadi dalam waktu yang relatif lebih singkat. Sedangkan pada penelitian yang dilakukan oleh Irawan dan Khudori (2015) kondisi mesofilik memberikan hasil yang lebih baik daripada termofilik dalam produksi biogas.

Tujuan dilaksanakannya penelitian ini adalah untuk menganalisa besarnya potensi biogas yang dapat diproduksi dari sampah organik rumah makan di Kota Pontianak dan mengetahui temperatur optimum untuk menghasilkan biogas dari sampah rumah makan di Kota Pontianak.

\section{Bahan dan Metode}

\subsection{Material}

Berbagai peralatan yang dimanfaatkan adalah sebagai berikut: kotak berukuran $500 \mathrm{~L}$, kantong plastik sampah $40 \mathrm{~L}$, timbangan, termokopel, reaktor batch $6 \mathrm{~L}$, dan tabung penampung. Analisis gas dilakukan dengan instrumen gas kromatorafi.

Sedangkan bahan-bahan yang digunakan meliputi sampah yang berasal dari rumah makan di Kota Pontianak, NaOH, EM-4, dan air.

\subsection{Sampling}

Teknik sampling dan proses analisanya dilakukan menggunakan metode SNI 19-39641994. Persentase komponen sampah ditentukan untuk mengetahui jumlah potensi sampah organik. Hal ini dilakukan dengan cara mengambil sampah organik yang ada dirumah makan untuk dijadikan sebagai sampel. Penentuan jumlah contoh yang diambil diperoleh dari persamaan berikut:

$$
\mathrm{S}=\mathrm{C}_{\mathrm{d} \downarrow} \text { Jumlah penduduk } / 6000
$$

Keterangan :

$\mathrm{S}$ = Jumlah sampel rumah makan

$\mathrm{C}_{\mathrm{d}}=$ Koefisien bangunan non perumahan $=1$

\subsection{Perhitungan Total dan Volatil Solid}

Sampah organik diambil $1.000 \mathrm{~g}$, kemudian dicacah dan ditimbang. Dioven pada temperatur $100-105^{\circ} \mathrm{C}$ dengan waktu 3-5 jam. Setelah itu, sampah organik kering yang diperoleh disimpan dalam desikator, kemudian ditimbang dan dioven kembali. Setelah dioven, massa sampah organik kering ditimbang, sehingga diperoleh total solid (TS). Selanjutnya sampah organik tersebut digunakan untuk menghitung volatile solid (VS). Sampah organik kering selanjutnya ditanur pada temperatur $600^{\circ} \mathrm{C}$ dengan waktu 40 menit. Kemudian sampah organik kering tersebut dimasukkan dalam desikator selanjutnya ditimbang sehingga diperoleh nilai VS.

\subsection{Perhitungan Potensi Volume Biogas}

Persentase rata-rata penyusutan sampah organik menjadi biogas dapat dituliskan dalam 
bentuk persamaan sebagai berikut (McDonald, dkk., 2008):

$\mathrm{Vb}=0,676 \times \mathrm{VS}$

dengan:

$\mathrm{Vb}=$ volume biogas $\left(\mathrm{m}^{3} / \mathrm{kg} \mathrm{VS}\right)$

\subsection{Produksi Biogas dengan Variasi Temperatur}

Sampah rumah makan yang telah dihaluskan menggunakan blender ditimbang sebanyak $4 \mathrm{~kg}$. Lalu dimasukkan ke dalam reaktor batch, kemudian ditambahkan air sebanyak 50\%, dan ditambahkan bakteri EM-4 sebanyak $25 \mathrm{~mL}$. Kemudian dilakukan pengadukan dan fermentasi selama 20 hari. Pada saat proses fermentasi dilakukan variasi temperatur $35^{\circ}, 40^{\circ}$, dan $55^{\circ} \mathrm{C}$. Adapun rangkaian alat pada penelitian dideskripsikan pada Gambar 1 berikut:

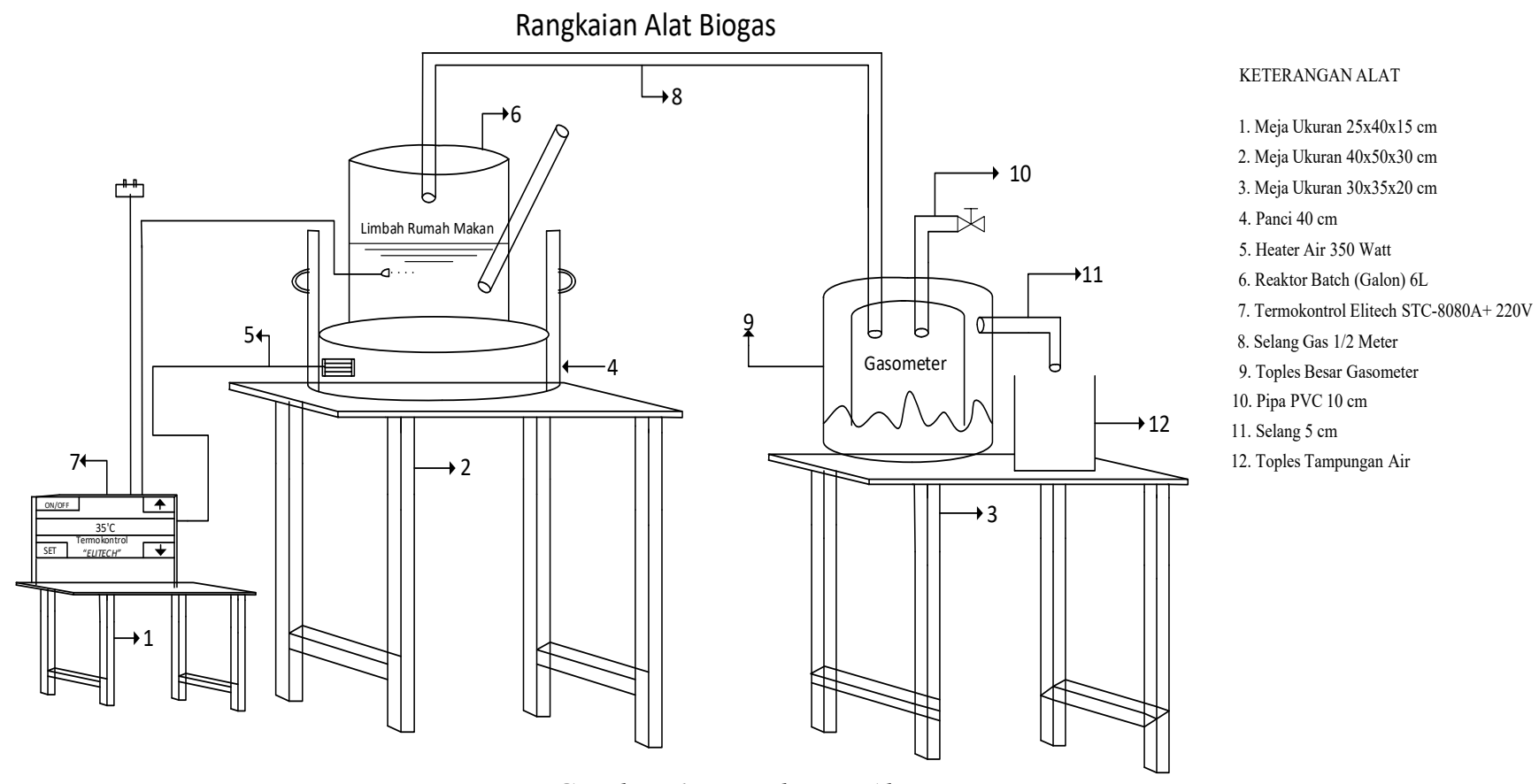

Gambar 1. Rangkaian Alat

\section{Hasil dan Pembahasan}

\subsection{Potensi Biogas dari Limbah Rumah Makan di Kota Pontianak}

Berdasarkan perhitungan menggunakan persamaan (1) di atas maka dalam penelitian ini diperlukan dua belas sampel rumah makan. Karena ada enam kecamatan di Kota Pontianak, maka masing-masing kecamatan diambil dua sampel rumah makan. Hasil sampling sampah rumah makan di wilayah Kota Pontianak dengan waktu 8 hari secara berkesinambungan berdasarkan metode SNI 19-3964-1994 terdapat pada Tabel 1:
Tabel 1. Jumlah Sampah Rumah Makan di Kota Pontianak

\begin{tabular}{lcc}
\hline \multicolumn{1}{c}{ Kecamatan } & Organik (kg) & $\begin{array}{l}\text { Anorganik } \\
(\mathbf{k g})\end{array}$ \\
\hline Pontianak Selatan & 57,423 & 4,854 \\
\hline Pontianak Utara & 30,685 & 5,023 \\
\hline Pontianak Barat & 24,548 & 4,018 \\
\hline Pontianak Timur & 64,421 & 6,067 \\
\hline Pontianak Tenggara & 28,230 & 4,621 \\
\hline Pontianak Kota & 61,370 & 10,046 \\
\hline Total & $\mathbf{2 6 1 , 3 4 7}$ & $\mathbf{3 4 , 6 3 0}$ \\
\hline Rata-Rata & $\mathbf{4 3 , 5 5 8}$ & $\mathbf{6 , 1 0 5}$ \\
\hline
\end{tabular}

Dari tabel tersebut di atas tampak bahwa jumlah rata-rata sampah organik yang dihasikan tiap rumah makan di Kota Pontianak adalah sebanyak 43,558 kg/hari. Dengan nilai rata-rata tersebut dapat diperoleh besarnya 
potensi biogas dengan melakukan analisis TS dan VS sebagaimana yang terdeskripsi pada tabel berikut:

Tabel 2. Hasil Analisa TS dan VS Sampah Organik Rumah Makan

\begin{tabular}{cccc}
\hline $\begin{array}{c}\text { Sampel } \\
\text { hari ke- }\end{array}$ & $\begin{array}{c}\text { Berat } \\
\text { awal } \\
\text { sampel } \\
\mathbf{( g )}\end{array}$ & $\begin{array}{c}\text { Berat } \\
\text { setelah } \\
\text { dioven } \mathbf{( g )}\end{array}$ & $\begin{array}{c}\text { Berat } \\
\text { setelah } \\
\text { difurnace } \\
\mathbf{( g )}\end{array}$ \\
\hline 1 & 20,0 & 15,3 & 7,1 \\
\hline 2 & 10,3 & 6,2 & 2,8 \\
\hline 3 & 13,2 & 5,1 & 2,3 \\
\hline 4 & 10,1 & 4,6 & 1,7 \\
\hline 5 & 10,0 & 3,3 & 2,1 \\
\hline Rata-rata & $\mathbf{1 2 , 7}$ & $\mathbf{6 , 9}$ & $\mathbf{3 , 2}$ \\
\hline
\end{tabular}

Sehingga diperoleh:

$$
\begin{aligned}
\mathrm{TS} & =\frac{6,9}{12,72} \times 100 \%=54,25 \% \text { Po } \\
& =54,25 \% \times 43,558 \mathrm{~kg} / \mathrm{hari}=23,630 \mathrm{~kg} \\
\mathrm{VS} & =\frac{3,2}{6,9} \times 100 \%=46,38 \% \mathrm{TS} \\
& =46,38 \% \times 23,630 \mathrm{~kg}=10,959 \mathrm{~kg} \\
\mathrm{Vb} & =0,68 \times \mathrm{VS}=0,68 \times 10,959 \mathrm{~kg} \\
& =7,408 \mathrm{~m}^{3} \mathrm{~kg}^{-1} \mathrm{VS}
\end{aligned}
$$

Dari perhitungan tersebut maka didapatkan jumlah rata-rata sampah organik rumah makan di Kota Pontianak yaitu 43,558 $\mathrm{kg} / \mathrm{hari}$ dengan potensi biogas yang dapat dihasilkan sebesar 7,408 $\mathrm{m}^{3} / \mathrm{kg} \mathrm{VS} /$ hari.

\subsection{Derajat Keasaman (pH)}

Salah satu faktor utama dalam pembentukan biogas adalah derajat keasaman $(\mathrm{pH})$, sebab aktivitas enzim yang diproduksi oleh mikroorganisme sangat dipengaruhi oleh nilai pH (Anugrah, dkk., 2017). Setiap kenaikan atau penurunan nilai $\mathrm{pH}$ akan membawa perubahan pada sistem biologis. Bakteri untuk membentuk $\mathrm{CH}_{4}$ dapat aktif pada suasana $\mathrm{pH} 7$ sampai 9, oleh sebab itu perlu dilakukan pengaturan $\mathrm{pH}$ sehingga biogas dapat diproduksi dengan maksimal (Suryani, dkk., 2018). Bakteri metanogen sangat rentan terhadap perubahan $\mathrm{pH}$. Proses anaerobic digestion sebaiknya berlangsung pada kisaran $\mathrm{pH} 6-8$ dengan $\mathrm{pH}$ optimal kurang lebih 7 (Pambudi, dkk., 2018; dan Dwivannie, dkk., 2019).
Substrat yang berupa sampah organik dari rumah makan atau restoran yang sudah diseragamkan dengan cara dihaluskan memiliki $\mathrm{pH}$ awal yang masih asam sehingga perlu dikondisikan dengan menambahkan $\mathrm{NaOH}$ agar $\mathrm{pH}$ menjadi netral. Substrat dengan $\mathrm{pH} 7$ adalah kondisi yang ideal untuk memproduksi biogas. Suasana $\mathrm{pH}$ optimum akan menstimulus tumbuh maksimalnya mikroorganisme pengurai, sehingga dapat meningkatkan produksi biogas. Berikut adalah nilai $\mathrm{pH}$ dari rentang waktu $0 \mathrm{~s} / \mathrm{d} 20$ hari selama proses anaerobic digestion berlangsung terdapat pada Tabel 3.

\section{Tabel 3. Nilai pH Substrat Sampah Rumah Makan}

\begin{tabular}{cccc}
\hline $\begin{array}{c}\text { Variasi } \\
\text { Temperatur } \\
\left({ }^{\mathbf{0}} \mathbf{C}\right)\end{array}$ & 0 Hari & 15 Hari & 20 Hari \\
\cline { 2 - 4 } 35 & 7 & 4,3 & 3 \\
\hline 45 & 6,9 & 4,3 & 3 \\
\hline 55 & 7 & 6 & 4,3 \\
\hline
\end{tabular}

Proses produksi biogas diawali dengan reaksi hidrolisis, asidogenesis, asetogenesis, dan metanogenesis. Sesudah kurang lebih satu minggu, bakteri telah mulai beradptasi dan berkembang biak di dalam reaktor. Sejalan dengan perkembangbiakkan bakteri maka proses pembusukan dan penguraian senyawa organik yang ada pada substrat menjadi efektif. Dari data $\mathrm{pH}$ yang diperoleh, tampak telah terjadi penurunan derajat keasaman dari hari permulaan hingga hari ke-20. Di 7 hari pertama umumnya terjadi proses hidrolisis dimana ion $\mathrm{H}^{+}$umumnya dilepaskan untuk mengkatalisis proses disosiasi ikatan polimer pada karbohidrat, protein, dan lemak sehingga pH akan relatif asam. Mikro organisme obligat anaerob serta sebagian bakteri anaerob fakultatif terlibat pada reaksi asidogenesis. Selanjutnya $\mathrm{pH}$ mengalami penurunan yang disebabkan oleh pembentukan volatile fatty acid yang berupa asam butirat, propionat, dan asetat. Asam-asam organik tersebut selanjutnya didegradasi menjadi metana dan karbondioksida.

\subsection{Pengaruh Temperatur dalam Produksi Biogas}

Penelitian ini menggunakan sampah rumah makan sebagai substrat dengan temperatur reaktor pada kondisi mesofilik 
$35^{\circ} \mathrm{C}$ dan $45^{\circ} \mathrm{C}$ serta termofilik $55^{\circ} \mathrm{C}$. Pada kondisi termofilik produksi biogas maksimum dihasilkan dalam durasi yang lebih singkat, sedangkan waktu yang lebih panjang diperlukan untuk memperoleh nilai maksimum produksi biogas pada temperatur mesofilik jika dikomparasikan dengan suhu termofilik sebagaimana yang terdapat pada Gambar 2 .

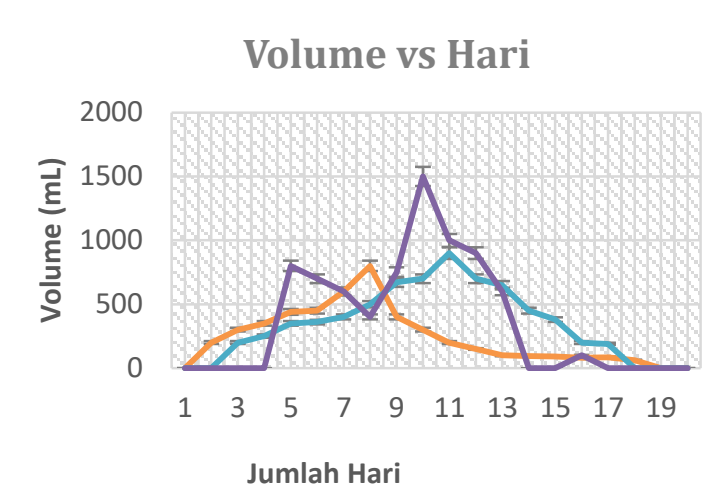

Ket: oranye $=35^{\circ} \mathrm{C}$, biru $=45^{\circ} \mathrm{C}$, ungu $=55^{\circ} \mathrm{C}$

\section{Gambar 2. Grafik hubungan volume terhadap produksi biogas per hari}

Dari grafik di atas tampak bahwa kondisi suhu dapat mempengaruhi proses fermentasi anaerobik dalam menghasilkan biogas. Dari variasi temperatur yang dilakukan pada kondisi mesofilik dan termofilik pada sampel sampah rumah makan yang difermentasi anaerobik selama 20 hari memberikan hasil yang berbeda pada produksi biogas. Pada temperatur termofilik hasil biogas yang diperoleh lebih tinggi dibandingkan dengan kondisi mesofilik. Sesuai dengan hal tersebut, penelitian yang dilakukan oleh Sari, dkk., (2018) dan Darmanto, dkk., (2012) pada kondisi mesofilik dan termofilik juga memberikan hasil yang serupa dimana pada temperatur termofilik perolehan biogas yang dihasilkan lebih banyak dibandingkan pada temperatur mesofilik.

Pada grafik di gambar 2, kondisi termofilik dengan suhu $55^{\circ} \mathrm{C}$ pada hari kedua perolehan gas bio yang diproduksi lebih banyak dibandingkan pada reaktor mesofilik dan dilanjutkan pada hari ke-5 digester termofilik jauh melebihi produksi mesofilik dalam menghasilkan biogas. Hal ini dikarenakan pada temperatur tinggi aktivitas bakteri sangat tinggi atau aktif. Bakteri termofilik berkembang biak lebih cepat dibandingkan dengan bakteri mesofilik. Pembelahan sel dalam proses pertumbuhan bakteri termofilik berlangsung lebih singkat sehingga pada tahap hidrolisis (hari ke 1 - 4) enzim yang dihasilkan oleh bakteri hidrolisis juga menjadi lebih banyak untuk mengubah bahan organik yang berupa polisakarida, lipid, serta protein menjadi senyawa monomer yang lebih sederhana. Enzim dan temperatur merupakan beberapa faktor yang dapat mempengaruhi laju reaksi biokimia, dimana tingginya konsentrasi enzim dapat mengkatalisis sehingga mempercepat terjadinya reaksi hidrolisis. Sementara peningkatan suhu menyebabkan bertambahnya tumbukan antar molekul.

Meningkatnya temperatur menyebabkan mikroorganisme aktif dan berkembang biak sehingga menguraikan material organik 2 sampai 3 kali lebih tinggi dibanding dengan pertumbuhan mikroorganisme di temperatur kamar. Oleh mikroorganisme, asam yang terbentuk dari reaksi hidrolisis kemudian dikonversi menjadi etanol. Asam amino dikonversi menjadi volatile fatty acid (VFA) seperti asam butirat dan asam propionat dimana di tahap berikutnya asam butirat, propionat dan alkohol dikonversi menjadi asam asetat. Asam asetat yang diproduksi pada rentang suhu $35^{\circ} \mathrm{C}$ sampai $55^{\circ} \mathrm{C}$ menunjukkan peningkatan terhadap kenaikan suhu hingga tercapai nilai produksi yang optimal pada suhu $55^{\circ} \mathrm{C}$.

Asam asetat yang diproduksi oleh mikroorganisme asam selanjutnya berinteraksi dengan enzim yang diproduksi mikroorganisme metanogen yang akan menghasilkan $\mathrm{CH}_{4}$ dan $\mathrm{CO}_{2}$. Reaksi metanogenesis berjalan seiring ketika asam asetat sebagai produk dari reaksi asidifikasi mulai terbentuk. Besarnya produksi volatile fatty acid yang dihasilkan oleh mikroorganisme fermentasi bergantung pada banyaknya mikroorganisme pada material organik.

Proses asidifikasi dan metanogenesis optimum pada hari ke-10 pada temperatur termofilik, dan pada hari ke-12 pada kondisi mesofilik. Setelahnya produksi biogas mengalami penurunan. Hal tersebut dikarenakan proses degradasi material organik mulai menipis untuk dikonversi menjadi asam lemak yang kemudian dikonversi oleh enzim 
yang diproduksi oleh mikroorganisme metanogen menjadi metan serta karbondioksida, sementara pada temperatur mesofilik perolehan biogas setelah hari ke-12 tidak menunjukkan penurunan secara cepat sebab pada temperatur mesofilik reaksi fermentasi berjalan lambat sehingga bahan organik belum semuanya terurai oleh mikroorganisme hidrolisis dan asidifikasi.

Penelitian ini dilaksanakan pada temperatur 30,45 , dan $55^{\circ} \mathrm{C}$, dengan menggunakan starter EM-4 (effective mikroorganism) yang merupakan tipikal mikroorganisme yang dapat aktif walaupun pada kondisi suhu yang tinggi di atas temperatur aktif umumnya mikroorganisme mesofilik yakni $45^{\circ} \mathrm{C}$. Dengan karakteristik yang dimiliki tersebut, maka mikroorganisme ini mayoritas berkembang dan hidup pada wilayah bertemperatur tinggi, misalnya di kawah gunung api, mata air panas, dan lokasi pembuatan kompos. Mikroorganisme tersebut mempunyai sistem tubuh yang memungkinkan untuk bertahan di suasana yang memiliki temperatur tinggi dimana protein atau enzim lainnya dapat terdenaturasi.

Produksi biogas pada temperatur $35^{\circ} \mathrm{C}$ dari hari ke-1 sampai selesai reaksi fermentasi anaerobik yaitu hari ke-20 menunjukkan kurva yang lebih landai jika dikomparasikan dengan kurva perolehan gas bio di temperatur termofilik yang relatif meningkat secara signifikan. Temperatur reaktor $55^{\circ} \mathrm{C}$ menghasilkan produksi biogas paling tinggi yaitu $7.350 \mathrm{~mL}$, pada temperatur $35^{\circ} \mathrm{C}$ produksi total biogas adalah $4.700 \mathrm{~mL}$, sedangkan pada temperatur $45^{\circ} \mathrm{C}$ diperoleh volume total biogas $6.900 \mathrm{~mL}$. Namun, hasil ini belum mencapai kondisi teoritis dimana seharusnya satu rumah makan mampu menghasilkan biogas rata-rata sebesar 7,408 $\mathrm{m}^{3} / \mathrm{kg} \mathrm{VS/} \mathrm{hari.}$

\subsection{Analisis Kadar Gas Metan}

Dari hasil analisis gas chromatography (GC), kandungan gas metan tertinggi terdapat pada reaktor dengan temperatur $35^{\circ} \mathrm{C}$, hal ini dimungkinkan karena masih adanya kebocoran pada sistem reaktor. Selain itu juga dimungkinkan terjadi lepasnya gas ke udara pada saat transfer gas ke dalam tabung untuk dianalisis GC. Konsentrasi gas metan pada setiap temperatur dideskripsikan dalam tabel berikut:

Tabel 4. Hasil Analisa dengan Instrumen GC

\begin{tabular}{ccc} 
No Sampel & $\begin{array}{c}\text { Temperatur } \\
\left({ }^{\mathbf{0}} \mathbf{C}\right)\end{array}$ & $\begin{array}{c}\text { Konsentrasi } \mathbf{C H}_{\mathbf{4}} \\
(\mathbf{p p m})\end{array}$ \\
\hline 1 & 35 & 257,79 \\
\hline 2 & 45 & 161,48 \\
\hline 3 & 55 & 197,63 \\
\hline
\end{tabular}

Dari uji nyala api yang sudah dilakukan diperoleh hasil jika api dapat menyala dengan baik sebagaimana yang terdapat pada gambar 3. Hal ini menunjukkan keberadaan gas metan yang terdapat dalam biogas.

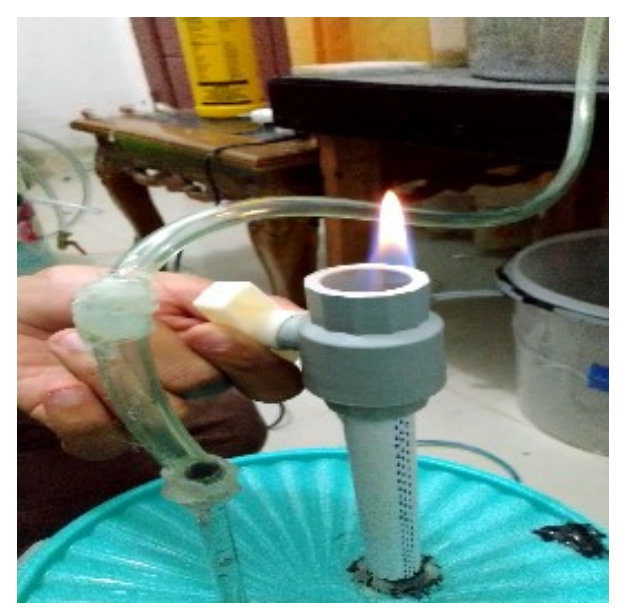

Gambar 3. Uji Nyala Biogas

\section{Kesimpulan}

1. Jumlah rata-rata sampah organik yang dihasilkan rumah makan di Kota Pontianak yaitu sebesar 43,558 kg/hari dengan potensi biogas yang dapat dihasilkan sebesar 7,408 $\mathrm{m}^{3} / \mathrm{kg}$ VS/ hari.

2. Temperatur reaktor $55^{\circ} \mathrm{C}$ menghasilkan produksi biogas optimum yaitu $7.350 \mathrm{~mL}$. Sedangkan pada temperatur $35^{\circ} \mathrm{C}$ diperoleh produksi total biogas adalah $4.700 \mathrm{~mL}$, dan pada temperatur $45^{\circ} \mathrm{C}$ diperoleh volume total biogas $6.900 \mathrm{~mL}$.

\section{Daftar Pustaka}

Anugrah, E.T., Nurhasanah, dan Nurhanisa, M. (2017). Pengaruh pH dalam Produksi Biogas dari Limbah Kecambah Kacang Hijau. Jurnal Prisma Fisika, Vol. 5(2), hal: 72-76. 
Badan Standarisasi Nasional. (1994). Metode Pengambilan dan Pengukuran Contoh Timbulan dan Komposisi Sampah Perkotaan. SNI.19-3964-1994.

Bong, C.P.C., Lim, L.Y., Lee, C.T., and Klemes, J.J. 2017. The Characterisation And Treatment of Food Waste For Important of Biogas Production During Anaerobic Digestion - AReview. Journal of Cleaner, Vol. 172, pp: 1545-1558.

Darmanto, A., Soeparman, S., dan Widhiyanuriawan, D. (2012). Pengaruh Kondisi Temperatur Mesophilic $\left(35^{\circ} \mathrm{C}\right)$ Dan Thermophilic $\left(55^{\circ} \mathrm{C}\right)$ Anaerob Digester Kotoran Kuda Terhadap Produksi Biogas. Jurnal Rekayasa Mesin, Vol.3(2), hal : 317-326.

Dewilda, Y., Aziz, R., dan Fauzi, M. (2019). Kajian Potensi Daur Ulang Sampah Makanan Restoran di Kota Padang. Jurnal Serambi Engineering, Vol. 4(2), hal: 482-487.

Dwivannie, V., Sasmita, A., dan Pratiwi, E. (2019). Karakteristik pH dan Suhu dalam Proses Pembuatan Biogas dari Substrat Limbah Rumah Makan, Limbah Cair Tahu dan Kotoran Sapi. JOM FTEKNIK Vol. 6, hal: 1-6.

Irawan, D., dan Khudori, A. (2015). Pengaruh Suhu Anaerobik Terhadap Hasil Biogas Menggunakan Bahan Baku Limbah Kolam Ikan Gurame. Turbo: Jurnal Program Studi Teknik Mesin, Vol. 4(1), hal: 17-22.

Kahar, A., Gunawan, R., Widodo, N.T., dan Alimuddin. (2019). Pengaruh Temperatur Pada Seeding dan Aklimatisasi Limbah Cair Pabrik Kelapa Sawit (POME) dalam Bioreaktor Anaerobik. Prosiding Seminar Nasional Ke-2 Tahun 2019 Hasil Riset dan Pengembangan Industri, hal: D1-8.

McDonald, T., Achari, G., Abiola, A. (2008). Feasibility of Increased Biogas Production from The Co-Digestion of Agricultural, Municipal, and Agro Industrial Wastes in Rural Communities. Jurnal of Environ. Eng. Sci., pp: 263-273.

Pambudi, S., Kirom, M.R., dan Suhendi, A. (2018). Pengaruh Kadar Keasaman
(pH) Terhadap Produksi Biogas dengan Menggunakan Campuran Kotoran Hewan Dan Substrat Kentang Busuk Pada Reaktor Anaerob. Proceeding of Engineering: Vol.5(3), hal: 5770-5776.

Rezeki, S. Ivontianti, W.D., dan Sitorus, K.A.P. (2019). Studi Potensi Konversi Sampah Organik Rumah Makan Menjadi Biogas Di Kota Pontianak. Prosiding Seminar Nasional Infrastruktur Energi Nuklir 2019, (hal: 483-489). Pontianak: Pusat Kajian Sistem Energi Nuklir BATAN.

Santoso, A.A. (2010). Produksi Biogas Dari Limbah Rumah Makan Melalui Peningkatan Suhu Dan Penambahan Urea Pada Perombakan Anaerob. Surakarta: Skripsi Jurusan Biologi, Universitas Sebelas Maret.

Sari, M.A., Kirom, M.R., dan Qurthobi, A. (2018). Analisis Pengaruh Temperatur Terhadap Produksi Biogas Pada Reaktor Anaerobic Buffled Reactor (ABR). Proceeding of Engineering : Vol.5(3), hal: 5602-5609.

Wahyono, E.H. dan Sudarmo, N. (2012). Biogas Energi Ramah Lingkungan. Bogor : Developing Collaborative Management of Cibodas Biosphere Reserve West Java.

Wati, D.S., dan Prasetyani, R.D. (2011). Pembuatan Biogas Dari Limbah Cair Industri Bioetanol melalui Proses Anaerob (Fermentasi). Semarang: Skripsi Jurusan Teknik Kimia, Fakultas Teknik, Universitas Diponegoro. 